\title{
Taraxacum mongolicum extract exhibits antimicrobial activity against respiratory tract bacterial strains in vitro and in neonatal rats by enhancing systemic Th1 immunity
}

\author{
Chengdong Sun*, Yan Wang, Xuemei Zhang \\ Department of Infectious Diseases, Beijing Jishuitan Hosipital, Beijing, 100009, China
}

${ }^{*}$ For correspondence: Email: SybleLath@yahoo.com; Tel: +86 1058516688

Sent for review: 20 April 2018

Revised accepted: 20 August 2018

\begin{abstract}
Purpose: To study the antimicrobial activity of the Taraxacum mongolicum extract against respiratory infection-causing bacterial strains in vitro and in neonatal rats.

Methods: The in vitro antibacterial activity was assessed by micro-dilution method. Antioxidant activity was determined by ferric reducing antioxidant power (FRAP), nitro blue tetrazolium (NBT) and 2, 2diphenyl-1-picrylhydrazyl (DPPH) assays. In vivo antimicrobial activity was evaluated in neonatal rat model. Interleukin (IL)-2 (IL-2) and gamma interferon (IFN-Y) were estimated using enzyme-linked immunosorbent assay (ELISA).

Results: The hydro-methanol extract of $T$. mongolicum contained high levels of phenolics and flavonoids, and exhibited strong antimicrobial activity against respiratory infection-causing bacterial species with MICs of $25-100 \mu \mathrm{g} / \mathrm{ml}$, and MBCs of $55-215 \mu \mathrm{g} / \mathrm{ml}$. The highest and lowest antimicrobial activities were observed against Streptococcus pneumonia and Haemophilus influenza, respectively. The extract at doses of 25 and $50 \mathrm{mg} / \mathrm{kg}$ exerted protective effects against Streptococcus pneumoniainfected neonatal rats by boosting their Th1 immunity. It enhanced the production of interleukin (IL)-2, concomitant with decreased production of interferon (IFN)- $y$ in neonatal rats. The extract contained isoetin, hesperidin, naringenin, kaempferol, sinapinic and gallic acid.

Conclusion: These results suggest that the hydro-methanolic extract of Taraxacum mongolicum and its constituents can be potentially developed for use in the management of respiratory bacterial infections.
\end{abstract}

Keywords: Respiratory tract infection, Interleukin, Taraxacum mongolicum, Immunity, Neonatal rats

\begin{abstract}
This is an Open Access article that uses a funding model which does not charge readers or their institutions for access and distributed under the terms of the Creative Commons Attribution License (http://creativecommons.org/licenses/by/4.0) and the Budapest Open Access Initiative (http://www.budapestopenaccessinitiative.org/read), which permit unrestricted use, distribution, and reproduction in any medium, provided the original work is properly credited.

Tropical Journal of Pharmaceutical Research is indexed by Science Citation Index (SciSearch), Scopus, International Pharmaceutical Abstract, Chemical Abstracts, Embase, Index Copernicus, EBSCO, African Index Medicus, JournalSeek, Journal Citation Reports/Science Edition, Directory of Open Access Journals (DOAJ), African Journal Online, Bioline International, Open-J-Gate and Pharmacy Abstracts
\end{abstract}

\section{INTRODUCTION}

Plants manufacture a wide array of metabolites that have been utilised as medicine since ages [1]. The plants of genus Taraxacum have been reported to be of immense pharmacological potential, having been utilised for the management of different diseases and disorders
[2]. A wide array of pharmacological properties such as anticancer and antimicrobial effects has been attributed to different extracts of Taraxacum species [3]. In the present study, the antimicrobial activity of Taraxacum mongolicum was evaluated against the common bacterial strains that cause respiratory infections. Respiratory infections are common and cause 
significant mortality and morbidity in humans. More than four million deaths across the globe were attributed to respiratory infections in 1990 alone [4].

Respiratory infections are caused mainly by several pathogenic bacteria which include but are not limited to Streptococcus pneumonia [5]. It has been reported that in infants, the immature immune system is subjected to antigens that are quite different from those it is challenged with later in life [6]. The development of immunity against antigens prevents the onset of diseases. However, failure to develop immunity against such antigenic challenges leads to development of respiratory infections. It has been reported that during the exposure of the infants to antigenic challenges, there is an imbalance between Thelper 1 (Th1) and Th2 immune responses [7].

Furthermore, due to control mechanisms involving gamma interferon (IFN- $\gamma$ ), the Th1 immune response is suppressed and the immune system of the infants becomes more biased towards Th2. This imbalance is often addressed after biological weaning. However, the production of IFN-y and IL-2 boosts the Th1 immunity which is beneficial to the health of the infants [8]. The present study was carried out to investigate the antimicrobial activity of hydro-methanol extract of Taraxacum mongolicum in vitro, as well as in neonatal rats. The study also determined the phytochemical composition of the extract.

\section{EXPERIMENTAL}

\section{Plant material and preparation of extract}

The fresh leaves of Taraxacum mongolicum were collected from natural habitats. The leaves were cleaned by washing in running water and then shade-dried and ground to fine powder. Hydro-methanol extract of the powder was prepared and the extracts was then stored at 4 ${ }^{\circ} \mathrm{C}$ under vacuum for further experimentation.

\section{Phytochemical analysis and antioxidant activity assays}

Total phenolic content was determined with Folin-Ciocalteu reagent as described earlier [9], while total flavonoid content was determined by the $\mathrm{AlCl}_{3}$ method of Chang et al [10]. Antioxidant activities were determined using DPPH, NBT and FRAP assays as described previously [11].

\section{Bacterial strains and antimicrobial activity}

The respiratory infection-causing bacterial strains Streptococcus pneumonia, Legionella pneumophila, Staphylococcus aureus, Klebsiella pneumoniae and Haemophilus influenzae were obtained from the Department of Infectious Diseases, Beijing Jishuitan Hosipital. For assessment of the antibacterial activity of the extract, the microdilution method was used. In essence, media containing varied concentrations of the extract $(256$ to $1.25 \mu \mathrm{g} / \mathrm{ml})$ were placed in a 96-well microplate. This was followed by the addition of the microbial cultures, with pure cultures and DMSO as control. Streptomycin was taken as positive control. The minimum inhibitory concentrations (MICs) and minimum bactericidal concentrations were determined as described previously [12].

\section{In vivo antibacterial activity}

A neonatal rat model was employed for the assessment of the antibacterial activity of the extract. Pregnant Wistar rats obtained from the animal holding capacity of Beijing Jishuitan Hosipital, Beijing, China were subjected to standard animal holding conditions and sterilized diet. After the gestation period, each dam littered 10 pups.

The pups were randomly put into four different groups. Group I received normal saline, group II was given $1 \mathrm{ml}$ of $S$. pneumonia $\left(10^{9} \mathrm{CFU} / \mathrm{mL}\right)$, group III received $1 \mathrm{ml}$ of $S$. pneumonia plus 25 $\mathrm{mg}$ of the extract, while group IV received $1 \mathrm{ml}$ of $S$. pneumonia plus $50 \mathrm{mg}$ of the extract once daily for four days. The degree of survival and weight of the pups after 9 days of treatment were determined.

\section{Isolation of spleen and primary cell preparations}

The neonatal rats were sacrificed and the spleen were isolated under aseptic conditions. The cells were extracted and the IL-2 and IFN-y levels were determined by ELISA as described previously [13].

\section{LC/MS analysis of the extract}

In order to identify its active constituents, chemoprofiling of the Taraxacum extract was performed by LC/MS analysis as described previously [14].

\section{Statistical analysis}

All experiments were carried out in triplicate, and the data are presented as mean \pm standard deviation (SD). Student's $t$-test was used for statistical analysis with the aid of GraphPad Prism 7 software. Values of $p<0.05$ were taken as indicative of significant difference. 


\section{RESULTS}

Hydro-methanol extract of $T$. mongolicum exhibited strong antioxidant activity

Phytochemical screening of the hydro-methanol extract of $T$. mongolicum revealed total phenolic content of $23.65 \mathrm{GAE} / \mathrm{g}$ dry weight (DW), while the total flavonoid content was $19.65 \mathrm{QE} / \mathrm{g} \mathrm{DW}$. Given the high amounts of phenolics and flavonoid contents, the antioxidant potential of the T. mongolicum extract was assessed by 3 different assays. DPPH assay showed that the extract inhibited DPPH radical in a concentrationdependent manner, with more than $70 \%$ inhibition at $50 \mu \mathrm{g} / \mathrm{ml}$ (Table 1).

In the DPPH assay, the antioxidant activity was comparable to that of ascorbic acid used as positive control. Similar observations were made in NBT assay (Table 2). However, in FRAP assay, the antioxidant activity was significantly lower than that of chlorogenic acid (positive control; Table 3).

Hydro-methanol extract of $T$. mongolicum inhibited the growth of respiratory infectioncausing bacterial strains

The results of antimicrobial assays revealed that the MIC of the extract was between 25 and 100 $\mu \mathrm{g} / \mathrm{ml}$. The lowest MIC of $25 \mu \mathrm{g} / \mathrm{ml}$ obtained was against $S$. pneumonia, while the highest MIC of $100 \mu \mathrm{g} / \mathrm{ml}$ was observed against $H$. influenzae (Table 4). The MBC values also showed the same trend and ranged between $55 \mu \mathrm{g} / \mathrm{ml}$ (against Streptococcus pneumonia) and 215 $\mu \mathrm{g} / \mathrm{ml}$ (against Haemophilus influenzae; Table 4).

Hydro-methanol extract of $T$. mongolicum exhibited antimicrobial activity in neonatal rats

The in vivo antibacterial activity of the extract of $T$. mongolicum was carried out in the neonatal rat model. The neonatal rats were orally administered the $S$. pneumonia alone or together with the extract at $25 \mathrm{mg}$ or $50 \mathrm{mg}$, while the control group received normal saline. It was observed that the percentage survival of the rats administered only normal saline was 90 (group 1 ), while a sudden decline in the \% survival was observed for neonatal rats orally administered $S$. pneumonia (Group II).

The \% survival in the group II rats was 40 only. However, the \% survival of the S. pneumoniatreated neonatal rats improved upon subsequent administration of 25 and $50 \mathrm{mg} / \mathrm{kg}$ of the extract.
The survival percentage of the rats administered $S$. pneumonia plus $25 \mathrm{mg} / \mathrm{kg}$ extract (group III) and $S$. pneumonia plus $50 \mathrm{mg} / \mathrm{kg}$ (group V) were 50 and $60 \%$, respectively (Figure 1).

Next, the effect of the extract on the Th1 immunity of the neonatal rats was evaluated. It has been reported that interleukin (IL)-2 production leads to the development of Th1 cells, and that interferon (IFN)- $y$ suppresses the Th1 cell development. Therefore, the productions of IL-2 and IFN- $\gamma$ were assessed in all the neonatal rat groups.

The results showed that the production of IL-2 was enhanced while that of IFN- $\gamma$ was reduced in $S$. pneumonia-infected neonatal rats concomitantly administered 25 or $50 \mathrm{mg} / \mathrm{kg}$ of the hydro-methanol extract of $T$. mongolicum (Figure 2).

LC/MS analysis revealed the presence of active constituents in the hydro-methanol extract of $T$. mongolicum

The active constituents of the hydro-methanol extract of $T$. mongolicum that could be potentially responsible for its antibacterial activity were identified by LC-MS analysis. The main compounds identified from the extract were isoetin, hesperidin, naringenin, Kaempferol, sinapinic and gallic acid (Figure 3).

Table 1: DPPH antioxidant potential of the hydromethanol extract of $T$. mongolicum

\begin{tabular}{lcc}
\hline $\begin{array}{l}\text { Concentration } \\
(\mu \mathrm{g} / \mathrm{ml})\end{array}$ & \multicolumn{2}{c}{ Inhibition (\%) } \\
\cline { 2 - 3 } & Extract & BHT \\
\hline 10 & $27 \pm 2$ & $67 \pm 2$ \\
20 & $45 \pm 2$ & $73 \pm 1$ \\
30 & $56 \pm 3$ & $79 \pm 2$ \\
40 & $62 \pm 2$ & $82 \pm 4$ \\
50 & $72 \pm 4$ & $84 \pm 3$ \\
\hline
\end{tabular}

The results are presented as mean $\pm \operatorname{SD}(n=3)$

Table 2: NBT assay showing the antioxidant potential of the hydro-methanol extract of $T$. mongolicum

\begin{tabular}{lcc}
\hline $\begin{array}{l}\text { Concentration } \\
(\mu \mathrm{g} / \mathrm{ml})\end{array}$ & \multicolumn{2}{c}{ Inhibition (\%) } \\
\cline { 2 - 3 } & Extract & $\begin{array}{c}\text { Ascorbic } \\
\text { acid }\end{array}$ \\
\hline 10 & $28 \pm 2$ & $67 \pm 2$ \\
20 & $47 \pm 1$ & $73 \pm 1$ \\
30 & $54 \pm 2$ & $79 \pm 2$ \\
40 & $63 \pm 4$ & $82 \pm 4$ \\
50 & $73 \pm 3$ & $84 \pm 3$ \\
\hline
\end{tabular}

The results are presented as mean $\pm \operatorname{SD}(n=3)$

Trop J Pharm Res, September 2018; 17(9): 1835 
Table 3: DPPH antioxidant potential of the hydromethanol extract of $T$. mongolicum

\begin{tabular}{lcc}
\hline $\begin{array}{l}\text { Concentration } \\
(\mu \mathrm{g} / \mathrm{ml})\end{array}$ & \multicolumn{2}{c}{ Absorbance $(\mathbf{7 0 0} \mathbf{~ n m})$} \\
\cline { 2 - 3 } & Extract & $\begin{array}{c}\text { Chlorogenic } \\
\text { acid }\end{array}$ \\
\hline 10 & $0.32 \pm 0.02$ & $1.05 \pm 0.07$ \\
20 & $0.51 \pm 0.02$ & $1.66 \pm 0.01$ \\
30 & $0.75 \pm 0.01$ & $2.56 \pm 0.05$ \\
40 & $0.77 \pm 0.04$ & $2.85 \pm 0.09$ \\
50 & $0.83 \pm 0.02$ & $3.56 \pm 0.08$ \\
\hline The results are & presented as & mean \pm SD of 3 \\
replicates & &
\end{tabular}

Table 4: Antibacterial activity of hydro-methanol extract of Taraxacum mongolicum (MICs and MBCs are expressed in $\mu \mathrm{g} / \mathrm{ml}$ )

\begin{tabular}{lcc}
\hline Bacterial strain & MIC & MBC \\
\hline Legionella pneumophila & $100 \pm 5$ & $210 \pm 3$ \\
Streptococcus pneumonia & $25 \pm 1$ & $55 \pm 3$ \\
Haemophilus influenza & $30 \pm 2$ & $70 \pm 4$ \\
Klebsiella pneumoniae & $50 \pm 3$ & $90 \pm 3$ \\
Staphylococcus aureus & $50 \pm 3$ & $95 \pm 3$ \\
Streptomycin & $14 \pm 3$ & $22.5 \pm 2$ \\
\hline
\end{tabular}



Figure 1: Effect of the T. mongolicum extract on normal and Streptococcus pneumonia-infected neonatal rats. The experiments were repeated three times and the results are expressed as mean $\pm \mathrm{SD}$; ${ }^{*} p$ $<0.05$ : Group I vs Group II; and ${ }^{\#} p<0.05$ for Group II vs Groups III and IV)
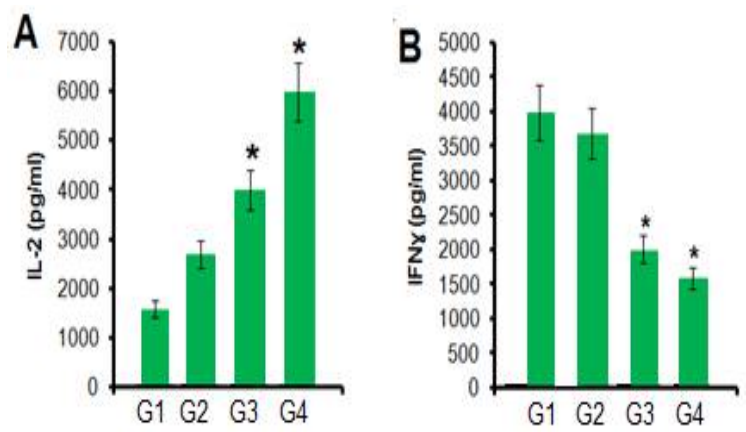

Figure 2: Effect of $T$. mongolicum extract on the production of $(A)$ IL-2 and (B) INF-y in different groups of neonatal rats $\left({ }^{*} p<0.05\right)$



Figure 3: Tentative identification of the active constituents of the hydro-methanol extract of $T$. mongolicum. (A) LC-MS chromatogram showing different peaks; (B) structures of the tentatively identified compounds. Peak 1: gallic acid, Peak 2: sinapinic acid, Peak 3: naringenin, Peak 4: kaempferol, Peak 5: isoetin, Peak 6: hesperidin

\section{DISCUSSION}

Respiratory infections are commonly caused by a number of bacterial species, and they lead to considerable mortality worldwide [15]. Although a number of antibiotics are used to overcome these bacterial infections, the emergence of drug resistance is prevalent among microorganisms. Drug-resistant bacterial strains are often difficult to treat [16]. Over the years, plants and plantderived products have been considered beneficial in the treatment of bacterial infections. Since a number of active compounds are present in plant extracts, it is believed that each antibacterial molecule may have a different target. Thus, these active components of plant extracts may act synergistically to suppress the growth of pathogenic bacteria and also prevent the emergence of drug resistance [17].

In the present study, the antibacterial activity of the hydro-methanol extract of $T$. mongolicum was evaluated against several bacterial strains in vitro and in neonatal rats in vivo. The result revealed that the $T$. mongolicum extract inhibited the growth of all the respiratory infection-causing bacterial species used in the study. These results are in agreement with previous findings. Indeed, $T$. mongolicum has been reported to exhibit broad spectrum antimicrobial activity [18]. Taraxacum has been shown to suppress the growth of pathogenic bacteria under in vitro conditions [19]. It is believed that plants produce a diversity to metabolites to prevent the growth of 
pathogens. Metabolites that inhibit the growth of plant pathogens also exhibit antimicrobial activity against human pathogens.

Flavonoids and phenolic compounds inhibit important bacterial enzymes, and also inhibit the cell wall biosynthesis and DNA replication in bacteria, thereby considerably suppressing bacterial growth [20]. Since T. mongolicum extract contains considerable amounts of phenolic compounds and flavonoids, these metabolites may be responsible for the observed antimicrobial activity against the tested bacterial strains. In order to further confirm the antibacterial effect of the extract, its antibacterial activity was assessed in neonatal rats. The results showed that administration of the $T$. mongolicum extract to $S$. pneumonia-infected neonatal rats improved their survival rate. Moreover, the extract boosted the Th1 immunity of the neonatal rats by enhancing the production of IL-2 and reducing the production of IFN-y. It has been reported that IL-2 production leads to the development of Th1 cells, while interferon (IFN)-y suppresses development of Th1 cells [6].

These results indicate that $T$. mongolicum exerts protective effects in neonatal rats by enhancing their Th1 immunity. Finally, to identify the active components of the extract, chemo-profiling led to the identification of isoetin, hesperidin, naringenin, kaempferol, sinapic and gallic acid. Previous studies have also reported the presence of these compounds in different species of Taraxacum. Moreover, these metabolites have known antimicrobial activities. Thus, they are likely to be responsible for the antimicrobial activity of the hydro-methanol extract of $T$. mongolicum.

\section{CONCLUSION}

Hydro-methanol extract of $T$. mongolicum exhibits significant antimicrobial activity against respiratory infection-causing bacteria. The extract also boosts the Th1 immunity of neonatal rats infected with respiratory infection-causing bacteria. The active constituents of the extract are mainly flavonoids and phenolic compounds. Thus, the hydro-methanol extract and its constituents may be useful in the management of bacterial infections.

\section{DECLARATIONS}

\section{Acknowledgement}

We thank Beijing Jishuitan Hosipital for providing access to the facilities used during this study.

\section{Conflict of interest}

No conflict of interest is associated with this work.

\section{Contribution of authors}

We declare that this work was done by the authors named in this article and all liabilities pertaining to claims relating to the content of this article will be borne by the authors. This study was designed and mainly performed by Chengdong Sun. Yan Wang and Xuemei Zhang assisted some parts of the experiments, including collected materials and manuscript revision.

\section{REFERENCES}

1. Fabricant DS, Farnsworth NR. The value of plants used in traditional medicine for drug discovery. Environ Health Perspect. 2001 Mar; 109: 69-75.

2. Schütz K, Carle R, Schieber A. Taraxacum-a review on its phytochemical and pharmacological profile. J Ethnopharmacol. 2006; 107(3): 313-323.

3. McIntosh K, Ellis EF, Hoffman LS, Lybass TG, Eller JJ, Fulginiti $V A$. The association of viral and bacterial respiratory infections with exacerbations of wheezing in young asthmatic children. J Pediat. 1973; 82(4): 578590.

4. Musher DM. How contagious are common respiratory tract infections? N Engl J Med. 2003; 348(13): 12561266.

5. Ball P, Baquero F, Cars O, File T, Garau J, Klugman K, Low DE, Rubinstein E, Wise R. Antibiotic therapy of community respiratory tract infections: strategies for optimal outcomes and minimized resistance emergence. J Antimicrob Chemother. 2002; 49(1), 31-40.

6. Bowman $L M$, Holt $P G$. Selective enhancement of systemic Th1 immunity in immunologically immature rats with an orally administered bacterial extract. Infect Immun. 2001; 69(6): 3719-3727.

7. Campbell JD, Gangur V, Simons FE, HayGlass KT. Allergic humans are hyporesponsive to a CXCR3 ligandmediated Th1 immunity-promoting loop. The FASEB J. 2004; 18(2): 329-331.

8. De Jong EC, Vieira $P L$, Kalinski $P$, Schuitemaker JH, Tanaka Y, Wierenga EA, Yazdanbakhsh M, Kapsenberg ML. Microbial compounds selectively induce Th1 cellpromoting or Th2 cell-promoting dendritic cells in vitro with diverse Th cell-polarizing signals. J Immunol. 2002; 168(4): 1704-1709.

9. Singleton VL, Orthofer $R$ and Lamuela-Raventós $R M$ 1999. Analysis of total phenols and other oxidation substrates and antioxidants by means of folin-ciocalteu reagent. In Methods in enzymology (299: 152-178). Academic press. 
10. Chang HC, Huang GJ, Agrawal DC, Kuo CL, Wu CR, Tsay HS. Antioxidant activities and polyphenol contents of six folk medicinal ferns used as "Gusuibu". Botanical Studies. 2007; 48(4):397-406.

11. Dave R. In vitro models for antioxidant activity evaluation and some medicinal plants possessing antioxidant properties: An overview. Afr J Microbial Res. 2009; 3(13): 981-996.

12. Balouiri M, Sadiki M, Ibnsouda SK. Methods for in vitro evaluating antimicrobial activity: A review. J Pharm Anal. 2016; 6(2):71-79.

13. Tian J, Zekzer D, Hanssen L, Lu Y, Olcott A, Kaufman $D L$. Lipopolysaccharide-activated $B$ cells down-regulate Th1 immunity and prevent autoimmune diabetes in nonobese diabetic mice. J Immunol. 2001; 167(2): 1081-9.

14. Baba SA, Malik AH, Wani ZA, Mohiuddin T, Shah Z, Abbas N, Ashraf N. Phytochemical analysis and antioxidant activity of different tissue types of Crocus sativus and oxidative stress alleviating potential of saffron extract in plants, bacteria, and yeast. $S$ Afr J Bot. 2015; 99: 80-87.

15. Bulla A, Hitze KL. Acute respiratory infections: a review. Bull World Health Organ. 1978; 56(3): 481-483.
16. Magiorakos $A P$, Srinivasan $A$, Carey RB, Carmeli $Y$, Falagas ME, Giske CG, Harbarth $S$, Hindler JF, Kahlmeter $G$, Olsson-Liljequist $B$, Paterson DL. Multidrug-resistant, extensively drug-resistant and pandrug-resistant bacteria: an international expert proposal for interim standard definitions for acquired resistance. Clin Microbiol Infect. 2012; 18(3): 268-281.

17. Nascimento GG, Locatelli J, Freitas PC, Silva GL. Antibacterial activity of plant extracts and phytochemicals on antibiotic-resistant bacteria. Braz $J$ Microbiol. 2000; 31(4): 247-256.

18. Sun CX, Tong YK, Huang L, Zhang LC. Antimicrobial activities of different solvent extracts from Taraxacum mongolicum Hand-Mazz. Food Sci Technol. 2012; 1: 5963.

19. Ionescu $D$, Predan $G$, Rizea $G D$, Mihele $D$, Dune $A$, Ivopol G, Ioniţă C. Antimicrobial activity of some hydroalcoholic extracts of artichoke (Cynara scolymus), burdock (Arctium lappa) and dandelion (Taraxacum officinale). Bull Transilvania Univ Braşov. 2013; 6: 113120.

20. Cowan MM. Plant products as antimicrobial agents. Clin Microbiol Rev. 1999; 12:564-582. 